\title{
REVOLUSI MENTAL UNTUK MEMBENTUK BUDAYA HUKUM ANTI KORUPSI
}

\author{
(Mental Revolution For Developing Anti-Corruption Legal Culture)
}

\author{
Arfan Faiz Muhlizi \\ Pusat Penelitian dan Pengembangan Sistem Hukum Nasional \\ Badan Pembinaan Hukum Nasional \\ Jl. Mayjen Sutoyo No.10 Cililitan Jakarta \\ Email: arfan_fm@yahoo.com
}

Naskah diterima: 15 Oktober 2014; revisi: 17 Nopember 2014; disetujui: 28 Nopember 2014

\begin{abstract}
Abstrak
Revolusi mental yang ditopang oleh kekuatan civil society adalah bagian dari penguatan budaya hukum ketika memandang hukum sebagai sebuah sistem. Terdapat beberapa fakta yang menunjukkan bahwa korupsi telah sedemikian meluas sehingga hampir semua elemen Negara, baik di eksekutif, legislatif maupun judiciil. Berpijak dari visi revolusi mental ini menarik untuk dibahas lebih jauh mengenai bagaimana pemberantasan korupsi bisa dilakukan dengan paradigma, budaya politik, dan pendekatan nation building baru yang lebih manusiawi, sesuai dengan budaya nusantara, serta bagaimana transformasi budaya nusantara dalam pemberantasan korupsi. Dengan pendekatan yuridis normatif diperoleh kesimpulan bahwa Nation Building pemberantasan korupsi berpijak prinsip supremasi hukum, kesetaraan di depan hukum dan penegakan hukum dengan cara-cara yang tidak bertentangan dengan hukum. Di sisi lain, terdapat anggapan bahwa sulitnya pemberantasan korupsi di Indonesia adalah akibat pemahaman bahwa korupsi adalah budaya bangsa. Pemahaman ini perlu diluruskan dengan menunjukkan bahwa budaya bangsa Indonesia adalah anti terhadap korupsi dan melakukan transformasi budaya. Transformasi budaya nusantara ke dalam format pembangunan hukum, khususnya pemberantasan korupsi, bersumber dari dua elemen yakni dari nilai-nilai agama dan dari nilai-nilai adat.
\end{abstract}

Kata kunci: revolusi mental, budaya hukum, moral, agama, adat

\section{Abstract}

Mental revolution supported by the strength of civil society is part of strengthening the legal culture as identify the law as a system. There are some facts showing how spreadable corruption it is in almost all elements of the nation, in the executive, legislative and judicial body. Based on the vision of mental revolution, it is interesting to discuss furthermore how corruption eradicating can be work with the new paradigms, political culture, and nation-building approach, which are humanly, likewise the national legal culture, and how the national culture-transformation in eradicating corruption. By normative juridical approach can be concluded that the nation building in combating corruption is based on the Supremacy of law principle, equality before the law and law enforcement in association with legal. On the other hand, there is a presumption that contraints of corruption eradicating in Indonesia because corruption has became a part of nation's culture. This presumption must be clarified that Indonesian genuine culture is anti corruption. National Cultural Transformation, especially in combating corruption, based on 2 (two) elements which are religious values and traditional values.

Keywords: mental revolution, legal culture, morals, religion, customs 


\section{A. Pendahuluan}

Pelaksanaan pemberantasan korupsi perlu didukung oleh konstruksi hukum nasional yang tangguh agar di satu sisi dapat menjaga karakter Negara Kesatuan Republik Indonesia (NKRI) dan di sisi lain upaya-upaya out of the box dapat dilaksanakan dengan kreatifitas yang mutakhir bagi pemberantasan korupsi. ${ }^{1}$ Presiden Republik Indonesia 2014-2019 yang baru saja terpilih melalui mekanisme demokrasi telah memberikan visi politik sebelum terpilih menjadi Presiden. Visi ini terkenal dengan sebutan "Revolusi mental". ${ }^{2}$ Istilah "mental" adalah nama bagi genangan segala sesuatu menyangkut cara hidup ${ }^{3}$. Di dalam cara hidup ada cara berpikir, cara memandang masalah, cara merasa, mempercayai/meyakini, cara berperilaku dan bertindak. ${ }^{4}$ Inilah civil society yang merupakan gerakan para warga negara (citizens) untuk melaksanakan transformasi secara berkelanjutan bagi pemberadaban hidup bersama yang bernama Indonesia. ${ }^{5}$

Dalam konteks hukum, revolusi mental yang ditopang oleh kekuatan civil society ini adalah bagian dari penguatan budaya hukum (legal culture) ketika memandang hukum sebagai sebuah sistem. ${ }^{6}$ Lawrence M Friedman menegaskan bahwa budaya hukum merupakan suasana pemikiran sosial dan kekuatan sosial yang menentukan bagaimana hukum digunakan, dihindari atau disalahgunakan. Budaya hukum erat kaitannya dengan kesadaran hukum masyarakat. Semakin tinggi kesadaran hukum masyarakat maka akan tercipta budaya hukum yang baik dan dapat merubah pola pikir masyarakat mengenai hukum. ${ }^{7}$ Hukum sebagai suatu institusi sosial melibatkan peranan dari orang-orang yang tersangkut didalamnya. Roscoe Pound berpendapat, pembuat hukum haruslah mempelajari apa efek sosial yang mungkin ditimbulkan oleh institusi dan doktrin hukum, berbanding dengan efek yang mungkin ditimbulkan oleh sarana kontrol atau sarana rekayasa lain yang bukan hukum ${ }^{8}$. Sebagai kontrol sosial, Hukum berkedudukan sebagai aturan dan proses sosial yang mencoba mendorong perilaku yang baik dan berguna atau mencagah perilaku buruk, ini diungkapkan oleh Donald 
Black dalam bukunya The Behavior of Law, yang menyatakan bahwa hukum adalah kontrol sosial dari pemerintah ${ }^{9}$. Berkaitan dengan kontrol sosial ini, hukum akan selalu terkait dengan sistem hukum yang ada. Sistem hukum ini memiliki unsur-unsur yang berupa struktur, substansi, dan budaya hukum. Friedman ${ }^{10}$ menyatakan, pada Struktur dari sistem hukum, sistem hukum terus berubah namun bagian dari sistem ini mengalami perubahan dalam kecepatan yang berbeda. Begitupun dengan substansi dan budaya hukum.

Budaya hukum juga perlu dibangun di kalangan aparat penegak hukum. Hal ini penting mengingat bahwa penegakan hukum, khususnya pemberantasan korupsi, sangat bergantung pada seberapa kuatnya etika, integritas dan komitmen aparat penegak hukum itu sendiri. ${ }^{11} \mathrm{Hal}$ ini sejalan dengan pemikiran Romli Atmasasmita yang melihat bahwa salah satu masalah mendasar yang mendesak dan segera harus diselesaikan adalah masalah pemberdayaan birokrasi atau bureaucratic engineering. ${ }^{12}$ Komisi Ombudsman Nasional menunjukkan bahwa tumpulnya penegakan hukum di Indonesia disebabkan oleh perbuatan maladministrasi (maladministration) yang dilakukan penyelenggara negara, khususnya aparat penegak hukum (law enforcer) dan lembaga peradilan seperti penanganan yang berlarut-larut, bertindak sewenangwenang, pemalsuan dokumen, dan lainlain. ${ }^{13}$ Yang dimaksud dengan maladministrasi (maladministration) dalam suatu instansi pemerintah, yaitu adanya keputusan atau tindakan yang janggal (inappropriate), yang sewenang-wenang (arbitrary), menyimpang (deviate), bahkan melanggar ketentuan hukum, dan telah terjadi penyalahgunaan wewenang atau kesewenangan (abuse of power atau detournament de puvoir), juga jika terasa ada pelanggaran kepatutan (equity) yaitu sekalipun menurut hukum dapat dibenarkan, akan tetapi nyata-nyata atau dapat dirasakan telah terjadi ketidakadilan. Korupsi menyebabkan tidak efisiennya birokrasi dan meningkatnya biaya administrasi dalam birokrasi. Jika birokrasi telah dicemari oleh korupsi dengan berbagai bentuknya, maka prinsip dasar birokrasi yang rasional, efisien, dan kualifikasitidak akan pernah terlaksana, sehingga menurunkan kualitas birokrasi. ${ }^{14}$ Keadaan ini dapat menyebabkan meluasnya keresahan sosial, ketidaksetaraan sosial dan bahkan mungkin kemarahan sosial. ${ }^{15}$

$9 \quad$ Lawrence M Friedman, opcit. hlm.3.

10 ibid.

11 Arfan Faiz Muhlizi, "Bantuan Hukum Melalui Mekanisme Nonlitigasi Sebagai Saluran Penguatan Peradilan Informal Bagi Masyarakat Adat," Jurnal Rechtvinding Vol.2 No.1 (2013), hlm.67.

12 Romli Atmasasmita, Pengantar Hukum Kejahatan Bisnis, (Jakarta: Prenada Media, 2003) hlm. 17-19. Birokrasi yang dimaksud bisa diperluas pemaknaannya menjadi penyelenggara Negara, baik yang berada pada wilayah eksekutif, legislatif, maupun judicial. Bandingkan konsep ini dengan pandangan Roscue Pond tentang fungsi hukum sebagai social control dan social engineering.

13 Komisi Ombudsman Nasional, Ombudsman Indonesia Masa Lalu, Sekarang, dan Masa Mendatang, (Jakarta: Komisi Ombudsman, 2002)

14 Gunnar Myrdal, "Corruption, Its Cause and Effects”, dalam Arnold J. Heidenheimer (ed.), Political Corruption: Readings in Comparative Analysis, ed. 2, (New Jersey: Transaction Books, 1978) hlm. 541.

15 Tunku Abdul Aziz, Fighting Corruption: My Mission, (Kuala Lumpur: Konrad Adenauer Foundation, 2005), hlm. 60. 
Terdapat beberapa fakta yang menunjukkan bahwa korupsi telah sedemikian meluas sehingga hampir semua elemen Negara, baik di eksekutif, legislatif maupun judiciil telah terjangkiti virus korupsi ini. Terdapat beberapa hasil penelitian yang menunjukkan terjadinya judicial corruption telah menggurita pada setiap tahap proses peradilan. ${ }^{16}$ Puncak korupsi di wilayah judiciil terjadi ketika Akil Mochtar, Ketua Mahkamah Konstitusi saat itu ditangkap oleh KPK atas dugaan penyuapan pada awal Oktober 2013. Selain Akil Mochtar terdapat setidaknya 10 orang Hakim lain yang terlibat kasus korupsi. ${ }^{17}$ Begitu juga di wilayah eksekutif, sederet nama Kepala Daerah juga terseret kasus korupsi. Bahkan data dari Kementerian Dalam Negeri tahun 2013 menunjukkan sebanyak 290 kepala daerah sudah berstatus tersangka, terdakwa, dan terpidana karena terbelit kasus. Di antara kasus tersebut sebanyak 251 orang kepala daerah atau sekitar 86,2 persen terjerat kasus korupsi. ${ }^{18}$ Sedangkan KPK mencatat total kepala lembaga atau kementerian yang terlibat ada 12 orang, duta besar 4 orang, komisioner 7 orang, gubernur 10 orang, wali kota atau bupati 35 orang, pejabat eselon 114 orang. ${ }^{19}$ Di wilayah legislatif pun data pelaku korupsi cukup memprihatinkan. Berdasarkan data KPK, 74 politikus terlibat dalam kasus korupsi pada 2007-2014. Jumlah tinggi terjadi pada 2010 sebanyak 27 orang dan 2012 ada 16 orang. ${ }^{20}$
Dari gambaran tersebut pelaku korupsi tersebut dapat dipetakan sebagai berikut:

Tabel.1 Pelaku Korupsi berdasarkan Data KPK

\begin{tabular}{|c|c|c|c|}
\hline LINGKUP & JABATAN & JUMLAH & TOTAL \\
\hline Non Goverment & Swasta & 94 orang & 94 orang \\
\hline Legislatif & Anggota DPR & 74 orang & 74 orang \\
\hline Judiciil & Hakim & 10 orang & 10 orang \\
\hline \multirow[t]{7}{*}{ Eksekutif } & Kepala Lembaga Atau & 12 orang & 182 orang \\
\hline & Kementerian & & \\
\hline & Duta Besar & 4 orang & \\
\hline & Komisioner & 7 orang & \\
\hline & Gubernur & 10 orang & \\
\hline & Wali Kota Atau Bupati & 35 orang & \\
\hline & Pejabat Eselon & 114 orang & \\
\hline
\end{tabular}

Sumber: diolah kembali oleh Penulis dari Fransisco Rosarians, "KPK: 74 Anggota DPR Terlibat Korupsi", http:// www.tempo.co/read/ news/2014/ 04/15/078570877/ KPK-74-Anggota-DPR-Terlibat-Korupsi (diakses 16 September 2014)

Melihat gambaran perilaku koruptif berdasarkan data di atas maka sangatlah tepat untuk menangani hal ini tidak sebatas pada halhal yang bersifat kelembagaan (legal structure), tetapi membangun juga hal-hal yang bersifat kultural (legal culture) sebagaimana yang dimaksud dengan revolusi mental. Revolusi mental ini menciptakan paradigma, budaya politik, dan pendekatan nation building baru yang lebih manusiawi, sesuai dengan budaya nusantara, bersahaja, dan berkesinambungan. ${ }^{21}$

Berpijak dari visi revolusi mental ini menarik untuk dibahas lebih jauh mengenai bagaimana pemberantasan korupsi bisa dilakukan dengan 
paradigma, budaya politik, dan pendekatan nation building baru yang lebih manusiawi, sesuai dengan budaya nusantara? serta bagaimana transformasi budaya nusantara dalam pemberantasan korupsi?

\section{B. Metode Penelitian}

Berdasarkan permasalahan dan latar belakang di atas, penelitian ini dilakukan dengan menggunakan pendekatan yuridis normatif ${ }^{22}$ karena menggunakan data sekunder sebagai sumber utama, berupa berbagai peraturan perundang-undangan dan referensi dokumen lain yang terkait seperti hasil penelitian sebelumnya, serta data dari berbagai media, baik cetak maupun elektronik. Tradisi penelitian dengan menggunakan laporan media massa, khususnya surat kabar dan internet, semakin berkembang pesat selama beberapa dasawarsa terakhir, terutama di bidang kajian tindakan kolektif dan gerakan sosial. Penggunaan surat kabar sebagai sumber data dipandang penting terutama dalam situasi di mana sumber-sumber alternatif, seperti statisitik yang dikeluarkan pemerintah dipandang kurang memadai.

\section{Pembahasan}

\section{Nation Building Dalam Pemberantasan Korupsi}

Memudarnya karakter bangsa dan menurunnya kesadaran hukum masyarakat merupakan gejala perubahan sosial di dalam masyarakat. Salah satu sebab perubahan sosial tersebut adalah kontak atau konflik antar kebudayaan. Berubahnya orientasi tata nilai dari idealisme, harga diri, dan kebanggaan, menjadi orientasi pada uang, materi, duniawi, dan hal-hal yang sifatnya hedonistis semakin menunjukkan pudarnya karakter bangsa Indonesia. Dalam kenyataannya masih cukup banyak dikembangkan kebiasaankebiasaan yang salah, seperti tidak menepati waktu, ingkar janji, saling menyalahkan, dan mengelak tanggung jawab. Lebih parah lagi dalam kehidupan bermasyarakat kita masih sangat langka adanya keteladanan yang bisa menginspirasi ketaatan dan kesadaran hukum yang menunjukkan karakter bangsa.

Lemahnya kondisi sosial masyarakat yang mendukung tahap pengembangan menyebabkan terganggunya tahap pemantapan akibat adanya masyarakat yang saling tidak mempercayai, tidak ada saling menghargai (low trust society). Hal ini menunjukkan tidak terbangunnya karakter secara baik dalam kehidupan kita berbangsa dan bernegara. Perlu diingat, sebuah bangsa akan maju dan jaya bukan sekedar disebabkan oleh kekayaan alam, kompetensi, ataupun teknologi canggihnya, tetapi karena dorongan semangat dan karakter bangsanya.

Begitu banyaknya komponen dari kehidupan sosial yang mempengaruhi karakter dan ketaatan hukum generasi bangsa, sesungguhnya menunjukan bahwa pembentukan dan pemeliharaan karakter merupakan tanggung jawab kita semua. Para

22 Penelitian normatif adalah penelitian yang dilakukan dengan cara meneliti bahan pustaka atau data sekunder belaka. Pemikiran normatif didasarkan pada penelitian yang mencakup (1)asas-asas hukum, (2) sistematik hukum, (3) taraf sinkronisasi vertikal dan horisontal, (4)perbandingan hukum, (5)sejarah hukum. Lebih jauh tentang ini lihat Soerjono Soekanto dan Sri Mamudji, ibid, hlm,13-14. Lihat juga Soerjono Soekanto dan Sri Mamudji, Peranan dan Penggunaan Perpustakaan di Dalam Penelitian Hukum, (Jakarta: Pusat Dokumentasi Hukum Fakultas Hukum Universitas Indonesia, 1979) hlm.15. 
pemimpin bangsa sebagai subjek tauladan bagi masyarakat Indonesia, memiliki peran besar dalam memberikan contoh perilaku bernegara yang baik dan bernilai. Media informasi baik itu stasiun televisi ataupun penerbit media cetak juga memiliki andil dalam pembentukan karakter, karena media informasi mampu memberi arah terhadap masyarakat atas cara pandang dan orientasi sosial.

Upaya regulatif untuk memperberat ancaman hukum atau dengan lebih mengetatkan penataan ketaatan warga negara terhadap undang-undang saja, yang hanya bersifat insidentil dan kejutan, bukanlah merupakan tindakan yang tepat untuk meningkatkan ketaatan dan kesadaran hukum masyarakat. Metode ini hanya akan menghasilkan ketaatan sementara yang imitatif. Pada hakekatnya tidaklah cukup semata-mata sekedar meningkatkan kesadaran hukum masyarakat saja, tetapi perlu juga membina kesadaran hukum masyarakat.

Konstruksi hukum nasional sebagai penyangga NKRI dibangun di atas landasan konstitusional Undang-Undang Dasar Negara Republik Indonesia Tahun 1945 yang mengatakan secara jelas bahwa Indonesia adalah Negara yang berdasar atas kedaulatan rakyat (demokrasi) ${ }^{23}$. Di samping itu, Konstitusi juga memberikan pengakuan secara tegas kepada bahwa Indonesia adalah hukum (nomokrasi) $^{24}$ dan juga Negara yang berdasar atas ketuhanan (teokrasi) ${ }^{25}$. Bangunan inilah yang akan dijadikan sebagai Nation Building pemberantasan korupsi dengan berpijak pada 3 (tiga) prinsip, yaitu: supremasi hukum (supremacy of law), kesetaraan didepan hukum (equality before the law) dan penegakan hukum dengan cara-cara yang tidak bertentangan dengan hukum (due process of law). Dalam pelaksanaannya ketiga hal tersebut dijabarkan dalam bentuk: kekuasaan kehakiman atau peradilan yang merdeka; legalitas hukum dalam segala bentuknya (setiap tindakan negara/ pemerintah dan masyarakat harus berdasar atas dan melalui hukum); serta jaminan perlindungan hak-hak asasi manusia (HAM). Pijakan yang demikian selaras dengan fungsi hukum sebagai pemelihara dalam ketertiban dan keamanan, sebagai sarana pembangunan, sebagai sarana penegak keadilan, dan sebagai sarana pendidikan masyarakat ${ }^{26}$.

Jaminan perlindungan HAM berdasar pada pandangan bahwa hukum dan HAM merupakan satu kesatuan yang sulit untuk dipisahkan, keduanya seperti dua sisi dalam satu mata uang. Apabila suatu bangunan hukum dibangun tanpa memperhatikan penghormatan terhadap prinsip-prinsip dalam HAM, maka hukum tersebut dapat menjadi alat bagi penguasa untuk melanggengkan kekuasaannya (abuse of power). Sebaliknya, apabila HAM dibangun tanpa didasarkan pada suatu komitmen hukum yang jelas, maka HAM tersebut hanya akan menjadi bangunan yang rapuh dan mudah untuk disimpangi. Oleh karena itu dalam sebuah negara hukum, muncul sebuah korelasi yang sangat erat antara penerapan hukum dan penegakan HAM. Pembukaan Undang-Undang Dasar Negara Republik Indonesia Tahun 1945 
yang merupakan cerminan tekad para pendiri bangsa dalam membentuk Negara Indonesia, telah memberikan sinyal yang tegas bahwa Hukum dan HAM adalah satu kesatuan yang tidak dapat dipisahkan di negara ini.

Dalam alinea pertama Pembukaan UUD 1945, kata "perikemanusiaan" adalah menunjukkan inti dari HAM, sedangkan "perikeadilan" merupakan inti dari hukum yang ada di Indonesia. Dalam pelaksanaannya aturanaturan tentang HAM diaplikasikan ke dalam Pasal 28 A hingga 28J yang pada hakikatnya diadopsi dari Universal Declaration of Human Right. Walaupun keseluruhan Pasal 28 A sampai dengan Pasal $28 \mathrm{~J}$ tersebut saling berkaitan, tetapi dalam pelaksanaannya ketentuan yang menyatakan bahwa hak hidup, hak untuk tidak disiksa, hak kemerdekaan pikiran dan hati nurani, hak beragama, hak untuk tidak diperbudak, hak untuk diakui sebagai pribadi di hadapan hukum yang berlaku surut adalah hak asasi manusia yang tidak dapat dikurangi dalam keadaan apapun (pasal 28I) tetap harus dibatasi sesuai dengan ketentuan-ketentuan yang berlaku. Bangsa Indonesia beranggapan bahwa pelaksanaan HAM tetap harus memperhatikan karakteristik Indonesia. Selain itu, pelaksanaan hak asasi juga harus diimbangi dengan pelaksanaan kewajiban masing-masing individu sehingga dapat tercipta saling menghargai dan menghormati hak asasi tiap-tiap warga. Pembatasan tersebut diatur dalam Pasal $28 \mathrm{~J}$ dan dilaksanakan dengan pertimbangan moral, nilai-nilai agama, keamanan dan ketertiban umum.

Dalam rangka memberikan perlindungan HAM, perlu dipertegas bahwa korupsi adalah ancaman bagi kemanusiaan. Hal ini dikarenakan korupsi berakibat sangat berbahaya begi kehidupan manusia, baik aspek kehidupan sosial, politik, birokrasi, ekonomi, ${ }^{27}$ dan individu. Jika korupsidalam suatu masyarakat telah merajalela dan menjadi makanan masyarakat setiap hari, maka akibatnya akan menjadikan masyarakat tersebut sebagai masyarakat yang kacau, tidak ada sistem sosial yang dapat berlaku dengan baik. Setiap individu dalam masyarakat hanya akan mementingkan diri sendiri (self interest), bahkan selfishness. ${ }^{28}$ Tidak akan ada kerjasama dan persaudaraan yang tulus. Fakta empirik dari hasil penelitian di banyak negara ${ }^{29}$ menunjukkan bahwa korupsi berpengaruh negatif terhadap rasa keadilan sosial dan kesetaraan sosial. Korupsi menyebabkan perbedaan yang tajam di

27 Sejak tahun 1960-an telah muncul beberapa pandangan tentang pengaruh korupsi terhadap ekonomi. Umumnya berpendapat korupsi mempunyai pengaruh negatif terhadap ekonomi, corruption is toxic rather than a tonic. Akan tetapi ada pendapat yang berbeda, yaitu bahwa korupsi, dalam situasi dan keadaan tertentu serta dalam tahap tertentu dapat memberikan peran positif terhadap ekonomi, misalnya sebelum tahun 1997, Indonesia dan Thailand adalah negara yang sangat cepat perkembangan ekonominya, walaupun tingkat korupsinya sangat tinggi. Pandangan ini dikemukakan oleh Nathaniel H. Leff, J.S. Nye, David H. Bayley, dan Samuel Huntington. Lihat Fethi Ben Jomaa Ahmed, Corruption: A Sociological Interpretative Study with Special Reference to Selected Southeast Asian Case, Disertasi Doktor Philosophy, (Kuala Lumpur: Department of Antropology and Sociology, Faculty of Arts and Social Sciences, University of Malaya, 2003), hlm. 140-149.

28 M. Umer Chapra, Islam and Economic Challenge, (USA: IIIT and The Islamic Foundation, 1995), hlm. 220.

29 Misalnya penelitian di 37 negara Tahun 1998 oleh Gupta, Davoodi dan Alonso mendapati bahwa korupsi mempunyai dampak signifikan terhadap ketidaksetaraan sosial, baik dalam hal pendidikan, distribusi pertanahan dan pendapatan. Bahkan dampak korupsi terhadap pendapatan lebih kuat. Lihat Johan Graf Lambsdorff, Corruption in Empirical Research: A Review, Transparency International Working Paper, November 1999, hlm. 8-9. 
antara kelompok sosial dan individu baik dalam hal pendapatan, prestis, kekuasaan dan lainlain. ${ }^{30}$

Korupsi juga membahayakan terhadap standar moral dan intelektual masyarakat. Ketika korupsi merajalela, maka tidak ada nilai utama atau kemuliaan dalam masyarakat. Theobald menyatakan bahwa korupsi menimbulkan iklim ketamakan, selfishness, dan sinisism. ${ }^{31}$ Korupsi menyebabkan sikap individu menempatkan kepentingan diri sendiri di atas segala sesuatu yang lain dan hanya akan berfikir tentang dirinya sendiri semata-mata. Jika suasana iklim masyarakat telah tercipta demikian itu, maka keinginan publik untuk berkorban demi kebaikan dan perkembangan masyarakat akan terus menurun dan mungkin akan hilang. Pada wilayah politik, kekuasaan yang dicapai dengan korupsi akan menghasilkan pemerintahan dan pemimpin masyarakat yang tidak legitimate di mata publik. Jika demikian keadaannya, maka masyarakat tidak akan percaya terhadap pemerintah dan pemimipin tersebut, akibatnya mereka tidak akan akan patuh dan tunduk pada otoritas mereka. ${ }^{32}$ Praktik korupsi yang meluas dalam politik seperti pemilu yang curang, kekerasan dalam pemilu, money politics dan lain-lain juga dapat menyebabkan rusaknya demokrasi, karena untuk mempertahankan kekuasaan, penguasa korup itu akan menggunakan kekerasan ${ }^{33}$ atau menyebarkan korupsi lebih luas lagi di masyarakat. ${ }^{34} \mathrm{Di}$ samping itu, keadaan yang demikian itu akan memicu terjadinya instabilitas sosial politik dan integrasi sosial, karena terjadi pertentangan antara penguasa dan rakyat. Bahkan dalam banyak kasus, hal ini menyebabkan jatuhnya kekuasaan pemerintahan secara tidak terhormat, seperti yang terjadi di Indonesia, ${ }^{35}$ pada masa Orde Baru.

Dengan demikian, penegakan hukum dalam rangka pemberantasan korupsi perlu dimaknai secara lebih substanstif. Menurut Satjipto Rahardjo, penegakan hukum pada hakikatnya merupakan penegakan ide-ide atau konsep-konsep yang abstrak. Jadi menurutnya penegakan hukum merupakan usaha untuk mewujudkan ide-ide tersebut menjadi kenyataan ${ }^{36}$. Sorjono Soekanto, mengatakan bahwa "penegakan" hukum terletak pada kegiatan menyerasikan hubungan nilai-nilai yang terjabarkan di dalam kaidah-kaidah yang

Mahathir Mohamad, The Challenge, (Kuala Lumpur: Pelanduk Publication Sdn. Bhd., 1986), hlm. 144.

31 Robin Theobald, Corruption, Development and Underdevelopment, (London: The McMillan Press Ltd. 1990), hlm. 112; Lihat juga Syed Hussein Alatas, Rasuah; Sifat, Sebab, dan Fungsi, (Kuala Lumpur: Dewan Bahasa dan Pustaka, 1995) hlm. 183.

32 Mahathir Mohamad, op.cit., hlm. 62-65.

33 Pendekatan seperti ini juga berakibat pada: penghargaan terhadap HAM kurang terjamin, ada kecenderungan untuk menciptakan homogenitas pemikiran, berkembangnya nepotisme, dan tuduhan adanya invisible hand (tangan-tangan setan) atas kejadian yang tidak mendukung harmoni. Lebih jauh lihat Susetiawan, Harmoni, Stabilitas Politik dan Kritik Sosial, Kritik Sosial dalam Wacana Pembangunan, (Yogyakarta: UII Press, 1997), hlm. 17-18.

34 Robin Theobald, opcit. hlm. 128; Lihat juga Emil Salim, “Mungkinkah Ada Demokrasi di Indonesia”, dalam Elza Peldi Taher (ed.), Demokratisasi Politik, Budaya dan Ekonomi, (Jakarta: Yayasan Paramadina, 1994), hlm. 157159.

35. Sukardi Rinakit, The Indonesian Military After The New Order, Copenhagen S, Denmark: NIAS Press, 2005) hlm. 67-73.

36 Satjipto Rahardjo, Masalah Penegakan Hukum suatu Tinjauan Sosiologis, (Bandung: Sinar Baru, Tanpa Tahun), hlm. 15. 
mantap dan mengejewantah dan sikap tindak sebagai rangkaian penjabaran nilai-nilai tahap akhir ahli, untuk menciptakan, memelihara dan mempertahankan kedamaian pergaulan hidup ${ }^{37}$. Oleh karenanya penegakan hukum bukanlah semata-mata berarti pelaksanaan perundangundangan, walaupun di dalam kenyataan di Indonesia kecenderungannya adalah demikian, sehingga pengertian "law enforcement" begitu populer ${ }^{38}$. Penegakan hukum secara konkret adalah berlakunya hukum positif dalam praktik sebagaimana seharusnya patut ditaati. Oleh karena itu, memberikan keadilan dalam suatu perkara berarti memutuskan perkara dengan menerapkan hukum dan menemukan hukum in concreto dalam mempertahankan dan menjamin ditaatinya hukum materiil dengan menggunakan cara prosedural yang ditetapkan oleh hukum formal. ${ }^{39} \mathrm{Hal}$ ini tidak mungkin dilakukan tanpa adanya rekonstruksi idealism para penegak hukum.

Rekonstruksi idealisme merupakan bagian yang sangat penting dalam reformasi hukum, khususnya dalam upaya memberantas korupsi di Indonesia. Rekonstruksi ini tidak hanya perlu dilakukan di dalam lembaga penegakan, tetapi perlu juga bagi seluruh intelektual. Keberhasilan peranan elite intelekual dalam pelaksanaan pembangunan tidak bisa dilepaskan dari dukungan orientasi nilai budaya masyarakat. Dalam hal ini, kaum intelektual itu harus bersikap, berperilaku, dan bertindak sesuai dengan orientasi nilai budaya yang mendukung pembangunan Indonesia.
Sesuai dengan hal tersebut, terdapat setidaknya tiga hal yang diharapkan terjadi dan perlu dilakukan oleh golongan intelektual. Pertama, memperluas pendidikan dan pencerdasan kehidupan bangsa yang memperkuat peranan golongan terpelajar dalam perubahan kemasyarakatan dan pemerintahan. Kedua, dewasa ini perlu ditumbuhkan kembali idealisme di kalangan calon intelektual. Ketiga, memperluas bentuk-bentuk pengabdian profesionalisme ${ }^{40}$. Ketiga hal ini sangat penting dilakukan untuk memberikan kontribusi mengatasi berbagai persoalan bangsa, termasuk memberantas korupsi.

Ki Hajar Dewantoro dalam Kongres Taman Siswa yang pertama pada tahun 1930 ia menyebutkan, bahwa pendidikan umumnya berarti daya upaya untuk memajukan bertumbuhnya budi pekerti (kekuatan batin, karakter), pikiran (intelek), dan tubuh anak. Dalam Taman Siswa tidak boleh dipisahpisahkan bagian-bagian itu agar kita dapat memajukan kesempurnaan hidup, kehidupan dan penghidupan anak-anak yang kita didik selaras dengan dunianya. ${ }^{41}$ Dalam pengertian maha luas, pendidikan sama dengan hidup. Pendidikan adalah segala situasi dalam hidup yang mempengaruhi pertumbuhan seseorang. Pendidikan adalah pengalaman belajar. Oleh karena itu, pendidikan dapat pula didefinisikan sebagai keseluruhan pengalaman belajar setiap orang sepanjang hidupnya. Dalam pengertian yang maha luas, pendidikan berlangsung tidak dalam batas usia tertentu, tetapi berlangsung sepanjang hidup (lifelong), sejak ia lahir (bahkan

\footnotetext{
37 Soerjono Soekanto, Putusan-putusan yang Mempengaruhi Tegaknya Hukum, (Jakarta: BPHN, 1983), hlm. 3. 38 Ibid, hal. 4.

39 Sjachran Basah, Eksistensi dan Tolok Ukur Badan Peradilan Administrasi, (Bandung: Alumni, 1985), hlm. 14.

40 M. Dawam Rahardjo, Intelektual, Intelegensia dan Perilaku Politik Bangsa, (Yogyakarta: Mizan, 1993 ), hlm. 71.

41 Fuad Ihsan, Dasar-dasar Kependidikan, Cet. II. (Jakarta: Rineka Cipta, 2001), hlm. 5.
} 
sejak awal hidup dalam alam kandungan) hingga mati. ${ }^{42}$

Hukum sesungguhnya mengandung nilainilai kebenaran, kejujuran, keadilan, nilai kepercayaan dan cinta kasih antar sesama, yang hanya dapat diwujudkan oleh orang-orang yang mempunyai kualitas dan integritas tinggi dalam menghayati nilai-nilai tersebut. Sofian Effendi, mantan rektor UGM, pernah mengemukakan bahwa salah satu persoalan mendasar di bidang hukum adalah memang masalah pendidikan hukum. Sebagaimana juga dikemukakan oleh Mochtar Kusumaatmadja, ${ }^{43}$ tentang reformasi pendidikan dalam rangka pembinaan hukum nasional sangat dibutuhkan menghasilkan ahli hukum yang terlibat dalam proses pengambilan keputusan (decision making process), dan penetapan kebijaksanaan, tidak hanya sebagai petugas pelaksanan kebijakan. Para ahli hukum juga diarahkan untuk aktif terlibat dalam kegiatan legislatif secara aktif. Para ahli hukum di pengadilan, profesi hukum, dan pendidikan diharapkan memiliki orientasi terhadap kemajuan bangsa dan pembangunan (pembinaan hukum).

Kita tidak bisa berharap banyak kepada insan-insan hukum untuk menegakkan hukum dan keadilan, apabila mereka tidak diajari dan dibekali ilmu dengan baik. Padahal sistem pembelajaran yang berlangsung pada lembagalembaga pendidikan hukum yang ada sekarang ini adalah masih bersifat transfer pengetahuan belaka dan berorientasi positivistik, sehingga cenderung hanya mencetak tukang (legal mechanics) dan tidak membentuk perilaku calon insan-insan hukum yang memiliki integritas diri yang adil, jujur, dan humanis ${ }^{44}$

Secara sosiologis Satjipto Rahardjo mengemukakan bahwa lingkungan mempengaruhi perbuatan seseorang. ${ }^{45}$ Dibandingkan dengan lima puluh tahun yang lalu lingkungan kita sekarang memang jauh lebih korup. ${ }^{46}$ Selanjutnya beliau mengutip pendapat Geery Spence, seorang advokat senior Amerika Serikat mengatakan bahwa sebelum menjadi ahli hukum profesional, jadilah manusia berbudi luhur" (evolved person) lebih dulu. Kalau tidak, para ahli hukum hanya akan menjadi monster dari pada malaikat penolong. ${ }^{47}$ Sistem pendidikan harus diarahkan untuk membantu membangun identitas bangsa Indonesia yang berbudaya dan beradab, yang menjunjung tinggi nilai-nilai moral agama yang hidup di negara ini. Akses ke pendidikan yang terprogram, terarah, dan tepat sasaran oleh nagara dapat membantu kita membangun kepribadian sosial dan budaya Indonesia. ${ }^{48}$

42 Redja Mudyahardjo, Filsafat Ilmu Pendidikan, Suatu Pengantar (Bandung: Remaja Rosdakarya, 2001), hlm. 4546.

43 Mochtar Kusumaatmadja, Hukum, Masyarakat, Dan Pembinaan Hukum Nasional, (Bandung: Binacipta, 1976), hlm. 24-25.

44 Sofyan Effendi, "Sambutan Rektor Universitas Gadjah Mada pada pembukaan Simposium Peningkatan Kurikulum Fakultas Hukum dan metode Pangajaran yang mendukung Pembangunan Hukum Nasional," dilaksanakan pada 21-22 Juli 2004.

45 Satjipto Rahardjo, Kompas, Rabu 23 Mei 2007.

46 Ibid.

47 Ibid.

48 Joko Widodo, opcit 


\section{Transformasi Budaya Nusantara Dalam Pemberantasan Korupsi}

Selama ini terdapat anggapan bahwa sulitnya pemberantasan korupsi di Indonesia adalah akibat pemahaman bahwa korupsi adalah budaya bangsa. Pemahaman ini perlu diluruskan dengan menunjukkan bahwa budaya bangsa Indonesia adalah anti terhadap korupsi.

Indonesia adalah Negara yang bersifat pluralistik baik suku, budaya, bahasa, kepercayaan maupun agama. Keberagaman tersebut mengakibatkan keberagaman (pluralisme) hukum sebagai fakta yang tidak dapat dihindari. Konstitusi Indonesia secara tegas mengakui dan menghormati kesatuan masyarakat hukum adat beserta hak-hak tradisonalnya sepanjang masih hidup dan sesuai dengan perkembangan masyarakat dan prinsip Negara Kesatuan Republik Indonesia seperti yang diatur dalam Pasal 18 B ayat (2) UUD 1945.49 Mengingat sangat beragamnya budaya yang tersebar di Indonesia maka budaya nusantara diartikan sebagai sarana untuk mencapai tujuan negara dengan memperhatikan hal-hal sebagai berikut ${ }^{50}$ : a. mengarah pada cita-cita bangsa yaitu masyarakat adil dan makmur berdasarkan Pancasila ${ }^{51}$;

b. ditujukan untuk mencapai tujuan negara;

c. dipandu oleh nilai-nilai Pancasila sebagai dasar negara, yaitu: berbasis moral agama, menghargai dan melindungi hak asasi manusia tanpa diskriminasi, mempersatukan seluruh unsur bangsa, meletakkan kekuasaan di bawah kekuasaan rakyat, dan membangun keadilan sosial. ${ }^{52}$

Transformasi budaya nusantara ke dalam format pembangunan hukum, khususnya pemberantasan korupsi, bersumber dari 2 (dua) elemen penting ${ }^{53}$ : pertama, yang dihasilkan dari nilai-nilai agama; dan kedua, yang dihasilkan dari nilai-nilai adat. Budaya nusantara yang bersumber dari nilai agama antara lain dapat dilihat dari pandangan Islam yang menyatakan bahwa: "Tindak Pidana Korupsi untuk memperkaya diri dari harta negara adalah perbuatan zhalim (aniaya), karena kekayaan negara adalah harta yang dipungut dari masyarakat termasuk masyarakat miskin yang mereka peroleh dengan susah payah. Bahkan perbuatan tersebut berdampak sangat luas serta berdampak menambah kuantitas masyarakat

49 Lihat Pasal 18B ayat (2) UUD NRI 1945.

50 Bandingkan dengan Mahfud MD, Politik Hukum Menuju Pembangunan Sistem Hukum Nasional, Seminar Arah Pembangunan Hukum Menurut UUD 1945 Hasil Amandemen, dilaksanakan BPHN di Jakarta tanggal 29-31 Mei 2006. Dalam konteksi ini politik hukum diartikan sebagai arah yang harus ditempuh dalam pembuatan dan penegakan hukum guna mencapai cita-cita dan tujuan negara.

51 Saat orde baru tumbang muncul fobia terhadap Pancasila. Namun sekitar 2004 Azyumardi Azra menggagas perlunya rejuvenasi Pancasila sebagai faktor integratif dan salah satu fundamen identitas nasional. Lebih jauh lihat As'ad Said Ali, Negara Pancasila, (Jakarta: LP3ES, 2009) hlm. 50-51.

52 Hal ini penting untuk menghindari terjadinya resistensi masyarakat. Hal ini pada akhirnya akan menimbulkan suatu keadaan yang disebut "hukum yang tidur" (statutory dormancy). Lebih jauh lihat Bayu Dwi Anggoro, Perkembangan Pembentukan Undang-Undang Di Indonesia, (Jakarta: Konstitusi Press: 2014) hlm.145.

53 Bandingkan dengan Tim Sosialisasi MPR Periode 2009-2014, Empat Pilar Kehidupan Berbangsa dan Bernegara, (Jakarta: Setjen MPR RI, 2012), hlm. 107, yang menyatakan bahwa salah satu solusi menghadapi tantangan adalah dengan "menjadikan nilai-nilai agama dan nilai-nilai budaya bangsa sebagai sumber etika kehidupan berbangsa dan bernegara dalam rangka memperkuat akhlak dan moral penyelenggara Negara dan masyarakat." 
miskin baru". Pernyataan ini didasari oleh QS: Al - Maidah:33 yang mengatakan: "Sesungguhnya pembalasan terhadap orang-orang yang memerangi Allah dan Rasul-Nya dan membuat kerusakan dimuka bumi, hanyalah mereka dibunuh atau disalib, atau dipotong tangan dan kaki mereka bertimbal balik, atau dibuang dari negeri(tempat kediamannya). Yang demikian itu (sebagai) suatu penghinaan untuk mereka didunia, dan di akhirat mereka beroleh siksaan yang besar". Korupsi adalah perbuatan yang dikategorikan membuat kerusakan di bumi.

Lebih jauh hal ini dijelaskan dalam Fatwa Ulama Nahdlatul Ulama (NU) pada Munas Alim Ulama dari kalangan NU di Asrama Haji Pondok Gede, Agustus 2002 yang mengemukakan halhal sebagai berikut: (1) Dalam pandangan syariat, korupsi merupakan penghianatan berat (ghulul) terhadap amanat rakyat. Dilihat dari cara kerja dan dampaknya, korupsi dapat dikategorikan sebagai pencurian (sariqah), perampokan (nahb); (2) Pengembalian uang korupsi tidak menggugurkan hukuman. Karena tuntutan hukuman merupakan hak Allah, sementara pengembalian uang korupsi ke Negara merupakan hak masyarakat (hak adamiy). Hukuman yang layak untuk koruptor adalah potong tangan sampai dengan hukuman mati; (3) Money politics sebagai pemberian (berupa uang atau benda lain) untuk mempengaruhi dan atau menyelewengkan keputusan yang adil dan obyektif dalam pandangan syariat merupakan suap (risywah) yang dilaknat Allah, baik yang memberi (rasyi), yang menerima (murtasyi), maupun yang menjadi perantara (raaisyi). ${ }^{54}$
Dalam agama Kristen, korupsi juga sangat dilarang, karena:55 pertama, korupsi identik dengan mencuri. Dalam 10 Perintah Tuhan, larangan kedelapan adalah larangan untuk mencuri. 10 Perintah Tuhan adalah salah satu norma yang dituangkan di Alkitab Perjanjian Lama dan merupakan inti dari etika Alkitab Perjanjian Lama. Dalam Keluaran 20:15, Allah berfirman: Jangan mencuri. Sementara itu korupsi adalah mencuri dengan cara diam-diam, dengan cara halus mengurangi hak negara atau orang lain demi kepentingan pribadi. Larangan mencuri juga dikemukakan Yesus dalam bentuk yang berbeda, yaitu hukum mengasihi sesama manusia seperti diri sendiri (Matius 22: 39; Mark 12: 31; Lukas 10: 27). Hukum ini sama dengan hukum pertama, yaitu hukum untuk mengasihi Tuhan Allah dengan segenap hati dan dengan segenap akal budi.

Kedua, korupsi adalah perbuatan melanggar hukum. Firman Allah yang tertulis lengkap dalam Alkitab juga menyebutkan bahwa orang Kristen pun selain wajib taat perintahNya, juga berlaku sama terhadap hukum yang berlaku. Ini jelas tertulis dalam Roma13:3, yang menyatakan jika seorang berbuat baik, ia tidak usah takut kepada pemerintah (hukum), hanya jika ia berbuat jahat. Maukah kamu hidup tanpa takut terhadap pemerintah (hukum)? Perbuatlah apa yang baik dan kamu akan beroleh pujian daripadanya.

Ketiga, korupsi adalah pengingkaran kepada Tuhan yang Maha Memelihara Umatnya. Dari sisi iman Kristen, Allah telah tegas menyebutkan bahwa burung di udara saja dipeliharanya,

54 M.Syamsudin, Korupsi dalam Perspektif Budaya Hukum, Jurnal UNISIA, Vol. XXX No. 64 Juni 2007, hlm. $186-187$.

55 Vanderblank "Korupsi Menurut Agama Nasrani”, http://www.scribd.com/doc/55007481/Korupsi-MenurutAgama-Nasrani (diakses pada 1 Oktober 2014). 
apalagi manusia. Dengan demikian umat tak perlu ragu akan usaha yang dijalankannya selama berada di jalan Tuhan. Oleh karena itu, korupsi jelas merupakan pengingkaran terhadap keberadaan Tuhan dan jaminannya. Jaminanjaminan Tuhan dituliskan di Alkitab di ayat-ayat berikut ini: ${ }^{56}$

a. Paulus menyatakan menasehati Timotius dalam Timotius 6: 6: "adalah benar bahwa melayani Allah membuat orang menjadi sangat kaya jika mereka telah merasa puas dengan yang dimilikinya".

b. Di Matius 6: 25-26 disebutkan Karena itu Aku berkata kepadamu: "Janganlah kuatir akan hidupmu, akan apa yang hendak kamu makan atau minum, dan janganlah kuatir pula akan tubuhmu, akan apa yanghendak kamu pakai."

Keempat, korupsi adalah tanda ketamakan manusia. Tuhan sangat mengutuk manusia yang tamak. Dalam cerita-cerita di Alkitab, orang-orang tamak akan diberikan hukuman karena ketamakannya itu. Pada cerita Gehazi, pelayan Nabi Elisa yang mengambil pemberian Panglima Kerajaan Aram, yakni Naaman, atas kesembuhannya dari penyakit kusta. Alih-alih ingin mendapatkan hadiah yang ditolak Nabi Elisa, Gehazi malah mendapat tulah berupa kusta yang sebelumnya diderita Naaman (II R Raja-raja 5: 1-27).

Larangan korupsi juga ditemukan dalam agama Buddha yang mengatakan: "tujuan hidup yaitu nirwana (puncak), manusia korup akan tak bahagia", kemudian agama Hindu yang menyebutkan: "pemimpin korup tak akan hidup kembali, suap sebagai pintu masuk dosa, pendosa tak diakui oleh Tuhan dan kena karma", serta Konfusianis yang menyatakan: "pendidikan beretika, pengendalian diri, pemerintahan akan hancur bila rakyat sudah tak menaruh kepercayaan terhadapnya." 57

Budaya nusantara yang bersumber dari nilai adat $^{58}$ pun memperlihatkan bahwa perbuatan menerima manfaat hasil korupsi sebagai suatu perbuatan menikmati hasil kejahatan, bertentangan dengan norma hukum adat. Beberapa norma hukum adat tersebut di antaranya adalah: ${ }^{59}$

\section{a. Hukum Adat Suku Tengger}

Suku Tengger adalah sebuah suku yang tinggal di sekitar Wisata Gunung Bromo, Jawa Timur Indonesia,menempati sebagian wilayah Kabupaten Pasuruan, Lumajang, Probolinggo, dan Malang. Orang-orang suku Tengger mayoritas beragama Hindu taat. Mereka yakin merupakan keturunan langsung dari Majapahit. Nama Tengger berasal dari sejarah Gunung Bromo yaitu dari dari Legenda Roro Anteng dan Joko Seger yang diyakini sebagai asal usul nama Tengger, yaitu "Teng" akhiran nama Roro An-"teng" dan "ger" akhiran nama dari Joko Se"ger". Dalam wawancara penulis tanggal 20 Juli 2011 dengan Kepala Desa Ngadisari di Lereng

56 Ibid.

57 Prasidda Santika, "Korupsi dalam Perspektif Agama dan Budaya”, http://sosbud.kompasiana.com/2011/01/11/ korupsi-dalam-perspektif-agama-dan-budaya-332275.html (diakses pada 1 Oktober 2014).

58 Syarat-syarat pengakuan hukum adat adalah sesuai dengan perkembangan masyarakat dan sesuai dengan prinsip NKRI. Bandingkan dengan Yance Arizona dkk, Pancasila Dalam Putusan Mahkamah Konstitusi, (Jakarta: Epistema Institute, 2014) hlm. 53.

59 Lihat Juga Arfan Faiz Muhlizi, "Membangkitkan Budaya Nusantara Yang Anti Korupsi”, http://www.rechtsvinding. bphn.go.id/view/view_online.php?id=77 (diakses pada 8 Oktober 2014) 
Gunung Bromo Jawa Timur yang bernama Supoyo menyebutkan bahwa lembaga adat berperan sebagai sistem kemasyarakatan yang mengatur struktur hirarki sosial dan kelompok masyarakat, serta menjaganya pada suatu harmoni.

Dalam wawancara tersebut disebutkan juga bahwa Suku Tengger memiliki petunjuk yang mengarah kepada keharmonisan dan kelestarian dalam persaudaraan, seperti yang terdapat dalam lima petunjuk kesetiaan (sesanti pancasetia). Sesanti itu adalah taat dan hormat kepada adat (setya budaya), kata harus sesuai dengan perbuatan (setya wacana), selalu menepati janji (setya semaya), bertanggung jawab terhadap tugas (setya laksana) dan selalu membangun kesetiakawanan (setya mitra). Orang Tengger juga memiliki empat falsafah ketaatan: taat kepada Tuhan, taat kepada orang tua (termasuk para leluhur), taat kepada guru (orang yang memberikan pengetahuan atau ilmu kepada mereka), serta taat kepada pemerintah. ${ }^{60}$

\section{b. Hukum Adat Dayak Ngaju ${ }^{61}$}

Norma Hukum adat Dayak Ngaju melarang perbuatan mengambil manfaat dari hasil kejahatan yang dilakukan orang lain. Norma ini dikenal sebagai "denda adat jual beli barang curian" (Singer tadahan ramu). Si A kehilangan barang bernilai, kemudian diketahui barang itu ada di tangan C, dibelinya dari B. Maka A dapat menuntut berdasarkan pasal ini melalui pemangku adat agar barang yang ada pada C diperiksa dan diperkara adatkan. C dan B dapat dianggap sekongkol mencuri, barang kembali kepada si A terkecuali kalau C mampu membuktikan bahwa dia tidak bersalah.

Jual beli antara C-B menjadibatal, B dihukum bayar denda singer adat 75-180 kati ramu, jika barang itu bernilai 500 kati ramu. Ditambah dengan biaya pesta adat damai seperlunya dan biaya perkara ditanggung oleh yang bersalah. ${ }^{62}$ Hukum adat daya ngaju juga mengenal norma hukum lain yang melarang menikmati hasil kejahatan ang dilakukan orang lain, yaitu disebut sebagai, "denda adat menyembunyikan barang curian" (Singer pahaliman/milim takau).

Barang siapa yang ikut serta membeli, merahasiakan atau menyembunyikan barangbarang diketahuinya berasal dari hasil curian, lebih berat lagi jika hal itu dilakukan pada malam hari kemudian diketahui, walaupun mereka tidak ikut mencuri tapi dapat dianggap ikut membantu atau melindungi perbuatan jahat itu. Sanksi: perbuatan sedemikian dapat diancam hukuman sebesar 15-30 kati ramu sambil mengembalikan barang tersebut kepada pemiliknya dan menanggung ongkos perkara sesuai menurut adat setempat. ${ }^{63}$

\section{c. Hukum Adat Suku Samin}

Sejak dikenal umum dari zaman kolonial Belanda, orang Samin tinggal menyebar di

60 Ibid.

61 Prasidda Santika, "Korupsi dalam Perspektif Agama dan Budaya”, http://sosbud.kompasiana.com/ 2011/01/11/ korupsi-dalam-perspektif-agama-dan-budaya-332275.html (diakses pada 1 Oktober 2014).

62 Syarat-syarat pengakuan hukum adat adalah sesuai dengan perkembangan masyarakat dan sesuai dengan prinsip NKRI. Bandingkan dengan Yance Arizona dkk, Pancasila Dalam Putusan Mahkamah Konstitusi, (Jakarta: Epistema Institute, 2014) hlm. 53.

63 Lihat Juga Arfan Faiz Muhlizi, "Membangkitkan Budaya Nusantara Yang Anti Korupsi”, http://www.rechtsvinding. bphn.go.id/view/view_online.php?id=77 (diakses pada 8 Oktober 2014) 
daerah Bojonegoro, Tuban, Blora, Rembang, Grobogan, Pati, dan Kudus. Mereka berdomisili tidak menggerombol, melainkan terpencarpencar, misalnya, tiap desa terdapat 5-6 keluarga, tetapi solidaritas sosialnya menyatu. Orang Samin memiliki rasa religi yang kuat sehingga sering kali membuat para pendatang (tamu) merasa risi dan malu karena mereka sangat jujur, serta pemurah terhadap para tamu. Seluruh makanan yang mereka simpan disajikan kepada tamunya dan tidak pernah memikirkan berapa harganya. Masyarakat Samin memiliki jiwa yang polos dan terbuka. Mereka berbicara menggunakan bahasa Kawi dan bercampur bahasa Jawa ngoko dan sering kedengaran kasar.

Dalam pergaulan sehari-hari, baik dengan keluarganya, sesama pengikut ajaran, maupun dengan orang lain yang bukan pengikut Samin, orang Samin selalu beranjak pada eksistensi mereka yang sudah turun-temurun dari pendahulunya, yaitu "adanya saya karena kamu, adanya kamu karena saya," (Ono niro mergo ningsun, ono ningsun mergo niro). Ucapan itu menunjukkan bahwa orang Samin sesungguhnya memiliki solidaritas yang tinggi dan sangat menghargai eksistensi manusia sebagai makhluk individu, sekaligus sebagai makhluk sosial. Karena itu, orang Samin tidak mau menyakiti orang lain, tidak mau mengambil barang orang lain yang bukan haknya (petil jumput), tetapi juga tidak mau haknya dicuri (dimalingi). "Jangan dengki, berbuat jahat, iri hati, bertengkar, merampok, mencuri, dan menjambret, mengambil barang yang bukan miliknya, termasuk jika menemukan barang (Aja drengki srei, dahwen, kemeren, tukar padu, bedhog colong, begal kace aja dilakoni, apa maneh kutil jupuk, nemu wae emoh)." Ajaran Samin Surosentiko (1859-1914) itu terus bergaung dari generasi ke generasi masyarakat Sedulur Sikep. Pegangan dalam bersikap itu lestari melalui pendidikan dalam keluarga dan berelasi dengan sesama. ${ }^{64}$

Semua perbuatân mereka berawal dari baik, maka berakhirnya juga harus baik, begitulah ringkasnya. Bagi orang lain yang tidak memahami eksistensi orang Samin, mereka bisa jadi menyebutnya sebagai Wong Sikep, yang artinya orang yang selalu waspada. Atau disebut juga Wong Kalang karena orang lain akan menganggap ketidakrasionalan pikiran, keeksentrikan perilaku, dan ketidaknormalan bahasa. Tetapi, bagi sesama orang Samin selalu menyebut kepada orang lain Sedulur Tuwo. ${ }^{65}$

\section{d. Hukum Adat Suku Bugis}

Jauh berabad-abad lalu, lontara' Bugis sudah mengingatkan tentang bahaya korupsi. Pesan tersebut disampaikan lewat analogi tikus sebagai binatang yang paling mengganggu dan paling menjijikkan. Tikus digambarkan telah menggerogoti semua sumber kehidupan manusia. Tikus yang digambarkan merusak padi sebagai sumber kehidupan mulai dari ketika padi masih di sawah, di tempat penyimpanan sampai setelah padi telah dimasak menjadi nasi. Begitu pula seorang koruptor menggerogoti sumber kehidupan masyarakat disemua sektor kehidupan mulai dari yang kecil-kecil hingga

\footnotetext{
64 Hendriyo Widi, “Jujur Ala Sedulur Sikep”, http://megapolitan.kompas.com/read/2012/04/16/ 02044683/Jujur.ala. Sedulur.Sikep (diakses 1 Oktober 2014).

65 Ibid.
} 
yang besar-besar. Korupsi juga tidak mengenal tempat, mulai dari lapangan (pungutan liar) hingga didalam ruangan. Tikus juga digambarkan sebagai binatang kecil yang lincah dan pergerakannya sulit diketahui sehingga sulit pula dicegah.

Persis seperti korupsi yang sulit diketahui bagaimana tingkah lakunya terbukti dengan masih banyaknya kasus korupsi yang tidak terungkap. Selain itu, tikus juga digambarkan suka membuat lubang kecil kedalam peti penyimpanan harta. Melalui lubang itu, tikus masuk menggerogoti semua barang simpanan seseorang di dalam peti. Melalui lubang kecil itu pula binatang-binatang kecil lainnya ikut masuk kedalam peti. Analogi tersebut tepat menggambarkan aktivitas korupsi yang gemar memanfaatkan lubang-lubang kecil untuk mendapatkan keuntungan pribadi. Lubang kecil tersebut jika tidak ditutup segera akan menjadi jalur rutin bagi koruptor-koruptor yang lain untuk ikut mengambil keuntungan-keuntungan pribadi. Sedemikian mengganggunya tikus-tikus ini sehingga dijadikan ikon semua binatang yang tidak memiliki siri'.

Secara umum, nilai siri' ini diasosiasikan oleh masyarakat secara luas dengan kata malu. Pendapat umum ini dapat dibenarkan karena dari empat dari tujuh arti dari kata siri' memang diartikan sebagai malu. Namun demikian, siri' tidak dapat diartikan hanya dalam pengertian malu. B.F Mathes ${ }^{66}$ dalam kamusnya mencatat arti siri' dalam kata bahasa Belanda yaitu: beschaamd, scroomvallig, verlegen, scaamte, eergevoel, scande, wangunst. Ketujuh kata tersebut diterjemahkan secara berurut berarti: amat malu, dengan malu, malu sebagai kata sifat atau kata keadaan, perasaan malu menyesali diri, perasaan harga diri, noda atau aib, dengki. Jika disederhanakan maka akan didapatkan terjemahan kata siri' kedalam empat kata yaitu: malu, harga diri, aib dan dengki. Pengertian kata siri' yang lebih sederhana lagi diungkapkan oleh Errington ${ }^{67}$ menjadi dua hal yaitu harga diri dan malu. Pengertian yang lebih komprehensif tentang makna kata siri' dapat ditelusuri melalui pemikiran beberapa peneliti yang mengkaji masalah siri' ini. C.H. Salam Basjah dan Sappena Mustaringmembagi siri' ke dalam tiga golongan pengertian diantaranya: (1) Siri' yang berarti malu; (2) Siri' yang merupakan daya pendorong untuk menghilangkan (membunuh, mengasingkan, mengusir dll) apapun atau siapapun yang menyinggung perasaan mereka; (3) Siri' sebagai motivasi untuk berusaha atau bekerja dengan sungguh-sungguh. ${ }^{68}$ Dari beberapa pengertian diatas, dapat disimpulkan bahwa "orang bugis menghayati siri' sebagai panggilan yang mendalam dalam diri pribadinya, untuk mempertahankan suatu nilai yang dihormatinya."

\section{e. Hukum Adat Papua}

Dalam adat papua membunuh dan melarikan anak gadis orang memang dipandang sebagai kejahatan tetapi pelakunya mendapat apresiasi sebagai orang yang hebat oleh keluarga atau 
sukunya. Karena dianggap hebat maka keluarga atau sukunya rela mengumpul uang sebagai uang "tebus kepala" pada kasus pembunuhan yang akan dibayarkan kepada keluarga atau suku yang terbunuh. Tetapi dalam kasus pencurian, tak ada apresiasi kepada pelakunya sehingga pelaku harus menanggung sendiri perbuatannya. ${ }^{69}$ Ketika korupsi disamakan dengan mencuri maka secara adat papua para pelaku korupsi dipandang sebagai perbuatan tercela atau kejahatan yang tak diapresiasi sehingga pelakunya harus menanggung sendiri resikonya. Hal ini berbeda dengan kasus pembunuhan atau melarikan anak gadis orang. Dengan demikian korupsi menurut adat papua lebih tercela dibanding membunuh atau melarikan anak gadis. Dalam adat papua, pelaku pencurian dalam hal ini korupsi hukumnya adalah dipanah.

\section{f. Hukum Adat Jawa}

Dalam ajaran kejawen, terdapat dua bentuk ancaman besar yang mendasari sikap kewaspadaan (eling lan waspada), karena dapat menghancurkan kaidah-kaidah kemanusiaan, yakni; hawa nafsu (hawanepsu) dan pamrih. Manusia harus mampu meredam hawa nafsu dan melepas pamrihnya. Hawa nafsu (lauwamah, amarah, supiyah) secara kejawen diungkapkan dalam bentuk akronim, yakni apa yang disebut M5 atau malima, yang terdiri dari: mabuk-mabukan, main perempuan, mencuri, makan, berjudi (madat, madon, maling, mangan, main)..$^{70}$
Dalam perspektif kaidah Jawa, nafsu-nafsu merupakan perasaan kasar karena menggagalkan kontrol diri manusia, membelenggu, serta buta pada dunia lahir maupun batin. Nafsu akan memperlemah manusia karena menjadi sumber yang memboroskan kekuatan-kekuatan batin tanpa ada gunanya. Lebih lanjut, menurut kaidah Jawa nafsu akan lebih berbahaya karena mampu menutup akal budi. Sehingga manusia yang menuruti hawa nafsu tidak lagi menuruti akal budinya (budi pekerti). Manusia demikian tidak dapat mengembangkan segi-segi halusnya, manusia semakin mengancam lingkungannya, menimbulkan konflik, ketegangan, dan merusak ketentraman yang mengganggu stabilitas kebangsaan.

Pamrih merupakan ancaman ke dua bagi manusia. Bertindak karena pamrih berarti hanya mengutamakan kepentingan diri pribadi secara egois. Pamrih, mengabaikan kepentingan orang lain dan masyarakat. Secara sosiologis, pamrih itu mengacaukan (chaos) karena tindakannya tidak menghiraukan keselarasan sosial lingkungannya. Pamrih juga akan menghancurkan diri pribadi dari dalam, kerana pamrih mengunggulkan secara mutlak keakuannya sendiri (istilahnya Freud; ego). Karena itu, pamrih akan membatasi diri atau mengisolasi diri dari sumber kekuatan batin. Dalam kaca mata Jawa, pamrih yang berasal dari nafsu ragawi akan mengalahkan nafsu sukmani (mutmainah) yang suci. Pamrih mengutamakan kepentingan-kepentingan duniawi, dengan demikian manusia mengikat dirinya sendiri dengan dunia luar sehingga

69 Taufik R. Mubarak, "Korupsi Menurut Pandangan Adat Papua”, http://www.scribd.com/ doc/81643770/ Korupsi-Menurut-Pandangan-Adat-Papua (diakses 1 Oktober 2014).

70 Sabdalangit, "Kejawen: Permata Asli Bumi Nusantara yang Selalu Dicurigai Dan Dikambinghitamkan", http:// sabdalangit.wordpress.com/atur-sabdo-pambagyo/kejawen-ajaran-luhur-yang-dicurigai-dikambinghitamkan/ comment-page-4/ (diakses 1 Oktober 2014). 
manusia tidak sanggup lagi untuk memusatkan batin dalam dirinya sendiri. Oleh sebab itu pula, pamrih menjadi faktor penghalang bagi seseorang untuk mencapai "kemanunggalan" kawula gusti.

Pamrih itu seperti apa, tidak setiap orang mampu mengindentifikasi. Kadang orang dengan mudah mengartikan pamrih itu, tetapi secara tidak sadar terjebak oleh perspektif subyektif yang berangkat dari kepentingan dirinya sendiri untuk melakukan pembenaran atas segala tindakannya. Untuk itu penting dikemukakan bentuk-bentuk pamrih yang dibagi dalam tiga bentuk nafsu dalam perspektif Kejawen: (1) Nafsu selalu ingin menjadi orang pertama, yakni; nafsu golek menange dhewe; selalu ingin menangnya sendiri; (2) Nafsu selalu menganggap dirinya selalu benar; nafsu golek benere dhewe; (3) Nafsu selalu mementingkan kebutuhannya sendiri; nafsu golek butuhe dhewe. Kelakuan buruk seperti ini disebut juga sebagai aji mumpung. Misalnya mumpung berkuasa, lantas melakukan korupsi, tanpa peduli dengan nasib orang lain yang tertindas.

\section{Penutup}

Nation Building pemberantasan korupsi berpijak pada 3 (tiga) prinsip, yaitu: supremasi hukum (supremacy of law), kesetaraan di depan hukum (equality before the law) dan penegakan hukum dengan cara-cara yang tidak bertentangan dengan hukum (due process of law). Dalam rangka memberikan perlindungan HAM, perlu dipertegas bahwa korupsi adalah ancaman bagi kemanusiaan. Hal ini dikarenakan korupsi berakibat sangat berbahaya begi kehidupan manusia, baik aspek kehidupan sosial, politik, birokrasi, ekonomi, dan individu.

Di sisi lain, terdapat anggapan bahwa sulitnya pemberantasan korupsi di Indonesia adalah akibat pemahaman bahwa korupsi adalah budaya bangsa. Pemahaman ini perlu diluruskan dengan menunjukkan bahwa budaya bangsa Indonesia adalah anti terhadap korupsi dan melakukan transformasi budaya. Transformasi budaya nusantara ke dalam format pembangunan hukum, khususnya pemberantasan korupsi, bersumber dari dua elemen yakni dari nilai-nilai agama dan dari nilai-nilai adat seperti Adat Suku Tengger, Adat Dayak Ngaju, Adat Suku Samin, Adat Suku Bugis, Adat Papua, serta Adat Jawa.

Untuk itu perlu dilakukan rekonstruksi idealisme sebagai bagian yang sangat penting dalam reformasi hukum, khususnya dalam upaya memberantas korupsi di Indonesia. Rekonstruksi ini tidak hanya perlu dilakukan di dalam lembaga penegakan, tetapi perlu juga bagi seluruh intelektual melalui pembenahan sistem pendidikan. Keberhasilan peranan elite intelekual dalam pelaksanaan pembangunan tidak bisa dilepaskan dari dukungan orientasi nilai budaya masyarakat. Dalam hal ini, kaum intelektual itu harus bersikap, berperilaku, dan bertindak sesuai dengan orientasi nilai budaya yang mendukung pembangunan Indonesia. Sistem pendidikan harus diarahkan untuk membantu membangun identitas bangsa Indonesia yang berbudaya dan beradab, yang menjunjung tinggi nilai-nilai moral agama yang hidup di negara ini. Para pemimpin bangsa sebagai subjek tauladan bagi masyarakat Indonesia, memiliki peran besar dalam memberikan contoh perilaku bernegara yang baik dan bernilai. Media informasi baik itu stasiun televisi ataupun penerbit media cetak juga memiliki andil dalam pembentukan karakter, sehingga transformasi budaya nusantara melalui media informasi akan mampu 
memberi arah terhadap masyarakat atas cara pandang dan orientasi sosial.

\section{DAFTAR PUSTAKA}

\section{Buku}

Ahimsa-Putra, Heddy Shry, Patron \& Klien di Sulawesi Selatan: Sebuah Kajian FungsionalStruktural, (Yogyakarta: Kepel Press, 2007)

Ahmed, Fethi Ben Jomaa, Corruption: A Sociological Interpretative Study with Special Reference to Selected Southeast Asian Case, Disertasi Doktor Philosophy, (Kuala Lumpur: Department of Antropology and Sociology, Faculty of Arts and Social Sciences, University of Malaya, 2003)

Alatas, Syed Hussein, Rasuah; Sifat, Sebab, dan Fungsi, (Kuala Lumpur: Dewan Bahasa dan Pustaka, 1995)

Ali, As'ad Said, Negara Pancasila, (Jakarta: LP3ES, 2009)

Anggoro, Bayu Dwi, Perkembangan Pembentukan Undang-Undang Di Indonesia, (Jakarta: Konstitusi Press: 2014)

Arizona, Yance et. all, Pancasila Dalam Putusan Mahkamah Konstitusi, (Jakarta: Epistema Institute, 2014)

Atmasasmita, Romli, Pengantar Hukum Kejahatan Bisnis, (Jakarta: Prenada Media, 2003)

Aziz, Tunku Abdul. Fighting Corruption: My Mission, (Kuala Lumpur: Konrad Adenauer Foundation, 2005),

Basah, Sjachran, Eksistensi dan Tolok Ukur Badan Peradilan Administrasi, (Bandung: Alumni, 1985)

Chapra, M. Umer, Islam and Economic Challenge, (USA: IIIT and The Islamic Foundation, 1995)

Dawam, Rahardjo, Intelektual, Intelegensia dan Perilaku Politik Bangsa, (Yogyakarta: Mizan, 1993)

Friedman, Lawrence M, Hukum Amerika: Sebuah Pengantar (American Law: An Introduction), Penerjemah oleh Wishnu Basuki, (Jakarta: PT. Tatanusa, 2001)

Hamzah, Andi, Korupsi di Indonesia dan Pemecahannya, (Jakarta: Gramedia Pustaka Utama, 1991

Hartono, Sunaryati, Hukum Ekonomi Pembangunan Indonesia, (Bandung: Binacipta, 1988)

Heidenheimer, Arnold J, (ed.). Political Corruption: Readings in Comparative Analysis, ed. 2, (New Jersey: Transaction Books, 1978)
Herlambang, Kontribusi Norma Hukum Adat Dalam Pembaharuan Tindak Pidana Korupsi Di Indonesia, Jurnal Supremasi Hukum, 2011

Ihsan, Fuad, Dasar-dasar Kependidikan, Cet, II. (Jakarta: Rineka Cipta, 2001)

Komisi Ombudsman Nasional, Ombudsman Indonesia Masa Lalu, Sekarang, dan Masa Mendatang, (Jakarta: Komisi Ombudsman, 2002)

Kusumaatmadja, Mochtar, Hukum, Masyarakat, Dan Pembinaan Hukum Nasional, (Bandung: Binacipta, 1976)

Mattulada, Latoa: Suatu Lukisan Analitis terhadap Antropologi Politik Orang Bugis, (Yogyakarta: Gadjah Mada University, 1985)

Mohamad, Mahathir, The Challenge, (Kuala Lumpur: Pelanduk Publication Sdn. Bhd., 1986)

Mudyahardjo, Redja, Filsafat Ilmu Pendidikan, Suatu Pengantar (Bandung: Remaja Rosdakarya, 2001)

NN, Hukum Adat Daya Ngaju, Tanpa Penerbit dan Tahun

Poerwadarminta, WJS, Kamus Umum Bahasa Indonesia,( Jakarta: PN Balai Pustaka, 1982)

Rahardjo, Satjipto, Masalah Penegakan Hukum suatu Tinjauan Sosiologis, (Bandung: Sinar Baru, Tanpa Tahun)

Rahim, A. Rahman, Nilai-Nilai Utama Kebudayaan Bugis, (Yogyakarta: Penerbit Ombak, 2011)

Rinakit, Sukardi, The Indonesian Military After The New Order, Copenhagen S, Denmark: NIAS Press, 2005)

Soekanto, Soerjono dan Sri Mamudji, Penelitian Hukum Normatif: Suatu Tinjauan Singkat, edisi 1, cet.v, (Jakarta: PT Raja Grafindo Persada, 2001),

Soekanto, Soerjono. Putusan-putusan yang Mempengaruhi Tegaknya Hukum, (Jakarta: BPHN, 1983)

Soekanto. Soerjono dan Sri Mamudji, Peranan dan Penggunaan Perpustakaan di Dalam Penelitian Hukum, (Jakarta: Pusat Dokumentasi Hukum Fakultas Hukum Universitas Indonesia, 1979)

Susetiawan, Harmoni, Stabilitas Politik dan Kritik Sosial, Kritik Sosial dalam Wacana Pembangunan, (Yogyakarta: UII Press, 1997)

Syamsudin, M. Korupsi dalam Perspektif Budaya Hukum, Jurnal UNISIA, Vol. XXX No. 64 Juni 2007

Taher, Elza Peldi (ed.), Demokratisasi Politik, Budaya dan Ekonomi, (Jakarta: Yayasan Paramadina, 1994) 
Theobald, Robin. Corruption, Development and Underdevelopment, (London: The McMillan Press Ltd. 1990)

Theobald, Robin. Corruption, Development and Underdevelopment, (London: The McMillan Press Ltd., 1990)

Tim Sosialisasi MPR Periode 2009-2014, Empat Pilar Kehidupan Berbangsa dan Bernegara, (Jakarta: Setjen MPR RI, 2012)

Wibowo, Basuki Rekso. Pembenahan Administrasi Peradilan, (Jakarta: BPHN, 2012)

Widodo,Joko. Revolusi Mental, Kompas, Sabtu 10 Mei 2014

Wignjosoebroto, Soetandyo. Hukum, Paradigma, Metode dan Dinamika Masalahnya, Cet.1 (Jakarta: ELSAM dan HUMA, 2002)

Zakiya, Wasingatu dkk. Panduan Eksaminasi Publik, (Jakarta: Indonesia Corruption Watch (ICW), 2003)

\section{Makalah / Artikel / Prosiding / Hasil Penelitian}

Effendi, Sofyan, "Sambutan Rektor Universitas Gadjah Mada pada pembukaan Simposium Peningkatan Kurikulum Fakultas Hukum dan metode Pangajaran yang mendukung Pembangunan Hukum Nasional," pada 21-22 Juli 2004.

Lambsdorff, Johan Graf, "Corruption in Empirical Research: A Review," Transparency International Working Paper, November 1999

MD, Mahfud, "Politik Hukum Menuju Pembangunan Sistem Hukum Nasional," Makalah disampaikan pada Seminar Arah Pembangunan Hukum Menurut UUD 1945 Hasil Amandemen, dilaksanakan BPHN di Jakarta tanggal 29-31 Mei 2006

Muhlizi, Arfan Faiz, "Bantuan Hukum Melalui Mekanisme Nonlitigasi Sebagai Saluran Penguatan Peradilan Informal Bagi Masyarakat Adat", Jurnal Rechtvinding Vol.2 No.1 (2013)

\section{Internet}

Mubarak, Taufik R., "Korupsi Menurut Pandangan Adat Papua", http://www.scribd.com/ doc/81643770/Korupsi-Menurut-PandanganAdat-Papua (diakses 1 Oktober 2014)

Muhlizi, Arfan Faiz, "Membangkitkan Budaya Nusantara Yang Anti Korupsi", http://www. rechtsvinding.bphn.go.id/view/view_online. php?id=77 (diakses pada 8 Oktober 2014)

Purnomo, Wayan Agus, "Ini Daftar Kepala Daerah Tersandung Kasus Korupsi", http://www. tempo.co/read/news/ 2013/02/09/ 063460207 (diakses 16 September 2014)

Rosarians, Fransisco, "KPK: 74 Anggota DPR Terlibat Korupsi", http://www.tempo.co/ read/ news/2014/ 04/15/078570877/KPK74-Anggota-DPR-Terlibat-Korupsi (diakses 16 September 2014)

Sabdalangit, "Kejawen: Permata Asli Bumi Nusantara yang Selalu Dicurigai Dan Dikambinghitamkan", http://sabdalangit.wordpress.com/atursabdo-pambagyo/kejawen-ajaran-luhuryang-dicurigai-dikambinghitamkan/commentpage-4/ (diakses 1 Oktober 2014)

Santika, Prasidda, "Korupsi dalam Perspektif Agama dan Budaya", http://sosbud.kompasiana.com/ 2011/01/11/korupsi-dalam-perspektif-agamadan-budaya-332275.html (diakses pada 1 Oktober 2014)

Supelli, Karlina, "Mengartikan Revolusi Mental", http:// www.jokowi.id/ opini/ mengartikanrevolusi-mental/ (diakses 16 September 2014)

Vanderblank, "Korupsi Menurut Agama Nasrani", http://www.scribd.com/doc/55007481/ Korupsi-Menurut-Agama-Nasrani (diakses pada 1 Oktober 2014)

Widi, Hendriyo, "Jujur Ala Sedulur Sikep", http:// megapolitan.kompas.com/ read/ 2012/04/16/ 02044683/Jujur.ala.Sedulur.Sikep (diakses 1 Oktober 2014) 